\title{
Evidence from the Vredefort Granophyre Dikes points to crustal relaxation following basin-size impact cratering
}

\author{
Matthew S. Huber ${ }^{\text {a, }}$, Elizaveta Kovaleva ${ }^{\mathrm{a}}$, Martin D. Clark ${ }^{\mathrm{b}}$, Ulrich Riller ${ }^{\mathrm{c}}$, Francois D. Fourie ${ }^{\mathrm{d}}$ \\ ${ }^{a}$ Department of Earth Sciences, University of the Western Cape, Robert Sobukwe Road, 7535 Bellville, South Africa \\ ${ }^{\mathrm{b}}$ Department of Geology, University of the Free State, 205 Nelson Mandela Drive, 9300 Bloemfontein, South Africa \\ c Institut für Geologie, Universität Hamburg, Bundesstraße 55, 20146 Hamburg, Germany \\ ${ }^{\mathrm{d}}$ Institute for Groundwater Studies, University of the Free State, 205 Nelson Mandela Drive, 9300 Bloemfontein, South Africa
}

\section{A R T I C L E I N F O}

\section{Keywords:}

Vredefort dome

Crustal relaxation

Dynamic collapse

Impact melt rock dikes

Melt differentiation

Electrical resistivity

Horizontal extension

\begin{abstract}
A B S T R A C T
The timescale of the modification stage of basin-sized impact structures is not well understood. Owing to ca. 10 $\mathrm{km}$ of erosion since its formation, the Vredefort impact structure, South Africa, is an ideal testing ground for deciphering post-impact modification. Here, we present geophysical and geochemical evidence from the Vredefort Granophyre Dikes, which were derived from the - now eroded - Vredefort impact melt sheet. The dikes have been studied mostly in terms of their composition, while the timing and duration of their emplacement remain controversial. We examined the modern depth extent of five dikes, with three from the inner crystalline core of the central uplift, and two from the boundary between the core and the supracrustal collar of the central uplift, using two-dimensional electrical resistivity tomography. We found that the core dikes terminate near the present erosion surface (i.e., $<5 \mathrm{~m}$ depth). In contrast, the dikes at the core-collar boundary extend to a depth $\geq$ $9 \mathrm{~m}$. These observations suggest that the core dikes are exposed near their lowermost terminus. In addition, we obtained bulk geochemical composition of the dikes, finding that the andesitic composition phase is present in the core-collar dikes that is not found in the core dikes. The presence of this phase indicates the episodic emplacement of impact melt into subvertical crater floor fractures.

We conclude that the dike formation was protracted and occurred over a time span of at least $10^{4}$ years. The sequential formation of the Vredefort Granophyre Dikes points to horizontal extension of crust below the impact melt sheet above a kinematic velocity discontinuity, a crustal instability resulting from the dynamic collapse of the transient cavity.
\end{abstract}

\section{Introduction}

Impact melt in basin-sized impact craters forms thick horizontal sheets, as well as dikes and irregular melt bodies in target rock below the crater floor (Dence, 1971). Impact melt dikes, known as Granophyre Dikes, are present in the central part of the deeply-eroded Paleoproterozoic Vredefort impact structure in South Africa (Willemse, 1937). The dikes are exposed in the Vredefort Dome, which is an erosional remnant of the central uplift of the structure. The Dome is divided into the "core" composed of crystalline basement rock and the "collar" composed of the supracrustal overturned strata surrounding the core. To date, nine Granophyre Dikes have been described: four dikes crop out within the core, and five dikes lie within the core-collar boundary (Fig. 1). Dikes in the core are up to $20 \mathrm{~m}$ wide and up to $4 \mathrm{~km}$ long, whereas dikes along the core-collar boundary are up to $65 \mathrm{~m}$ wide and up to $9 \mathrm{~km}$ long (Therriault et al., 1996). The dikes formed later than impact-induced pseudotachylite bodies (Dietz, 1961; Dence, 1971; Bisschoff, 1988), contain on average $20 \mathrm{vol} \%$ fragments of shocked target rocks (French and Nielsen, 1990; Buchanan and Reimold, 2002; Kovaleva et al., 2019; Huber et al., 2021), and have a Re-Os signature indicative of a meteoritic component (Koeberl et al., 1996). Core dikes have predominantly spherulitic texture, whereas core-collar boundary dikes display granular texture. Therriault et al. (1996) attributed the prevalence of spherulitic textures of the Granophyre Dikes in the core, and the dominance of granular textures in the collar, to the depth of melt intrusion. According to Therriault et al. (1996), the core dikes have spherulitic textures because these melt portions crystallized closer to fracture termini. The authors also noted that dikes in the collar appear to be more mafic and

\footnotetext{
* Corresponding author.

E-mail address: mhuber@uwc.ac.za (M.S. Huber).
} 
ascribed this observation to assimilation of the surrounding mafic metavolcanic rocks of the Dominion Supergroup (Fig. 1).

Uncertainty exists regarding the mechanism of dikes formation, which is critical to resolve for identifying the timing of dike emplacement (Grieve and Therriault, 2000; Riller, 2005; Grieve et al., 2008). The formation of Granophyre Dikes has been mostly viewed as the result of emplacement of a compositionally homogeneous impact melt along fractures in target rocks (e.g., French et al., 1989; French and Nielsen, 1990; Lieger and Riller, 2012; Kovaleva et al., 2019). Based on field relationships at Vredefort, the majority of studies attribute intrusion of impact melt into crater floor fractures at "the later stages" of the cratering process, although this has variably been considered to mean within minutes to hours after the moment of impact, or even thousands of years later (e.g., Dietz, 1961; French et al., 1989; French and Nielsen, 1990; Therriault et al., 1996, 1997; Buchanan and Reimold, 2002; Dressler and Reimold, 2004; Fourie et al., 2019; Huber et al., 2020). Despite this uncertainty, it is clear that the emplacement of the dikes is not due to injection dikes that form coeval with cratering (e.g., Wittmann et al., 2004; Kenkmann et al., 2014), as this process does not account for observations regarding the Granophyre Dikes.

Lieger and Riller (2012) proposed that Granophyre Dikes formed during isostatic readjustment of the crust below the crater without proposing a time scale. They suggested that Granophyre Dikes are composed of at least two phases of impact melt, wherein the earlier melt was hotter, and therefore able to digest wall rock fragments, leaving behind a clast-poor zone, while the later melt was cooler, and therefore unable to effectively digest wall rock fragments, forming a clast-rich zone in the dikes. However, recent work has contested the ability of granophyric melt to sufficiently assimilate wall rock, and mechanisms of turbulent flow of very low viscosity melt have been proposed to explain the presence of clast-rich and clast-poor zones (Huber et al., 2021).

The generation of impact melt-filled fractures at the similarly-sized Sudbury impact structure, Canada, locally known as Offset Dikes, are also attributed by some authors to isostatic readjustment of crust below the crater (Wichman and Schultz, 1993; Hecht et al., 2008; Lafrance et al., 2014; Mathieu et al., 2021), or to excess fluid pressure from the melt sheet (Prevec and Büttner, 2018), which caused the periodic sporadic melt intrusions. The geochemical similarity between the Vredefort Granophyre Dikes and the Sudbury Offset Dikes has been established by numerical modeling (Huber et al., 2020).

Recently, Fourie et al. (2019) conducted a non-destructive geophysical survey of the Daskop Granophyre Dike in the core of the

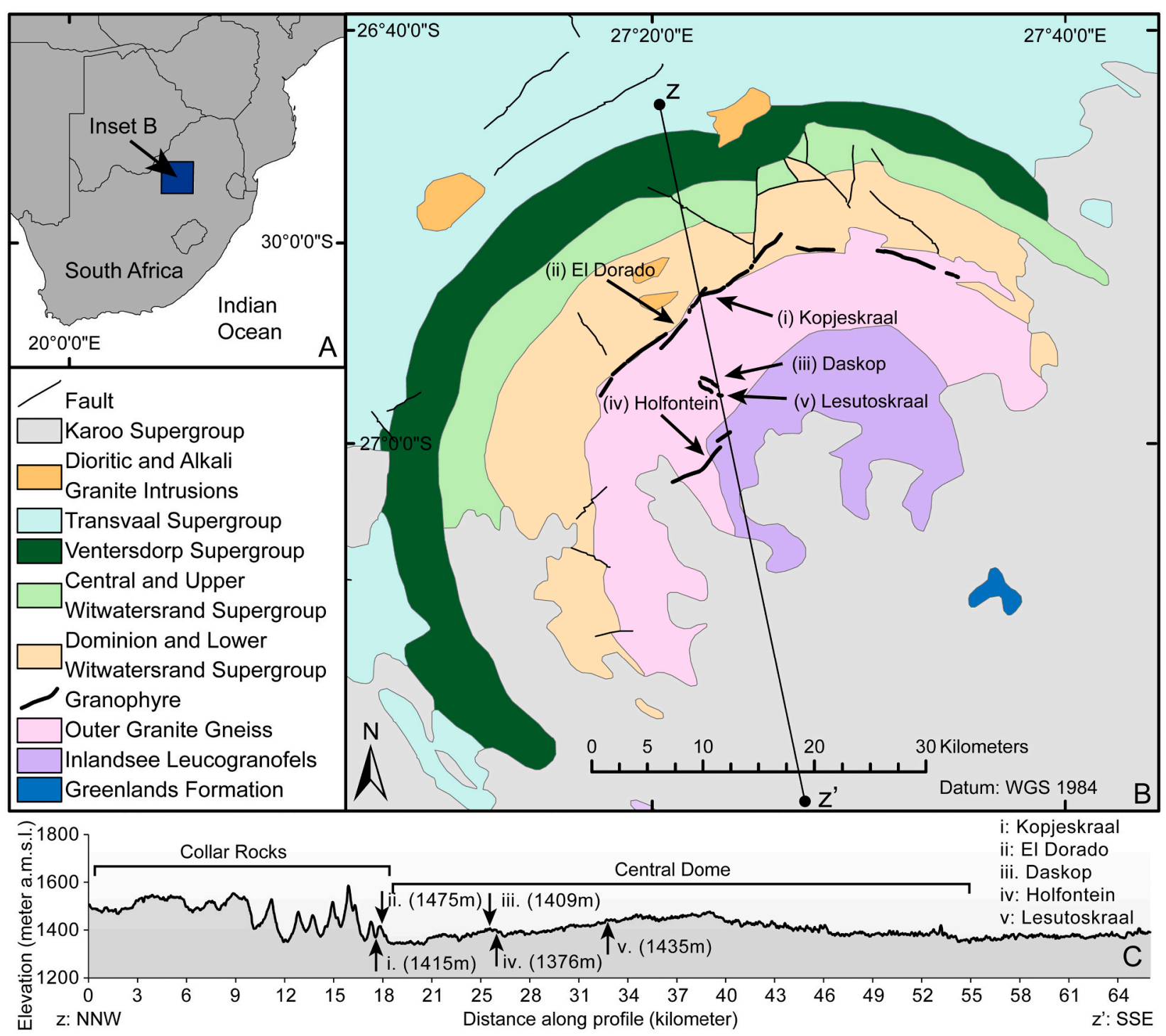

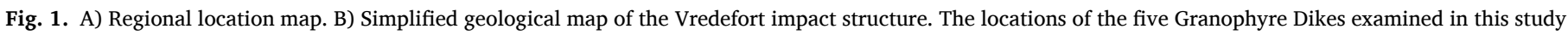

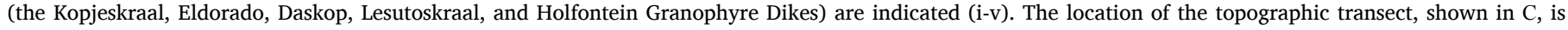
indicated (Z-Z). C) Topographic transect through the Vredefort impact structure with the locations of the dikes i-v. 
Vredefort impact structure that included magnetic and electrical resistivity studies and geophysical modeling. The results of this survey indicate that the dike terminates at a depth of $<3 \mathrm{~m}$ below the present erosion surface. Similarly, a geophysical survey of the Holfontein Granophyre Dike demonstrated a very shallow depth extent of both segments of the dike, with apparent confirmation of the shallow depth extent based on a construction trench cutting through the dike (Clark et al., 2021). Due to the World Heritage status of the area, no drilling of Granophyre Dikes has been undertaken to directly explore the depth extent of the dikes.

In this study, geophysical and geochemical data are utilized to constrain the mechanism and timing of Granophyre Dike emplacement. The results have implications for the evolution of basin-sized impact craters on the rocky planetary bodies at geological timescales.

\section{Geological setting}

The upper portions of the 2.02 Ga Vredefort impact structure (Kamo et al., 1996; Moser, 1997; Fig. 1), including the impact melt sheet, have been removed due to an estimated 8-10 km of erosion (Schreyer, 1983; Gibson et al., 1998). The central uplift of the impact structure is known as the Vredefort Dome (Bisschoff, 1988; Gibson et al., 1998) and consists of Archean crystalline basement rocks forming its core, and upturned to overturned metasedimentary and metavolcanic strata of the collar. Collar rocks to the NW of the Dome form a ring syncline, known as the Potchefstroom Synclinorium, and extend the diameter of the structure to approximately $150 \mathrm{~km}$ (Friese et al., 1995). Based on geophysical data and numerical modeling, the initial diameter of the impact structure is estimated between 180 and $300 \mathrm{~km}$ (Henkel and Reimold, 1998; Ivanov, 2005). Uplifted Archean basement rocks in the core are exposed at an elevation between 1340 and $1480 \mathrm{~m}$ above mean sea level (mamsl), whereas the rocks in the collar rise to 1590 mamsl (Fig. 1C).

The Granophyre Dikes are characterized by an igneous texture (Therriault et al., 1996) and a dacitic chemical composition with little variability. The most felsic Granophyre Dikes reach $69.2 \mathrm{wt} \%$ of $\mathrm{SiO}_{2}$ and $3.0 \mathrm{wt} \% \mathrm{MgO}$, whereas the most mafic dikes have $63.7 \mathrm{wt} \%$ of $\mathrm{SiO}_{2}$ and $4.2 \mathrm{wt} \%$ of $\mathrm{MgO}$ (French and Nielsen, 1990). The average composition of the Granophyre Dikes is $67.0 \mathrm{wt} \% \mathrm{SiO}_{2}$ and $3.5 \mathrm{wt} \% \mathrm{MgO}$ (Therriault et al., 1997). The bulk trace elements composition is remarkably similar between the dikes (e.g., Therriault et al., 1997; Kovaleva et al., 2018). Inhomogeneous distribution of lithic clasts has been documented within the dikes, with clast-rich portions located along the margins of the dikes (Therriault et al., 1996; Huber et al., 2021). Pegmatitic veins are present within Granophyre Dikes and have been interpreted as evidence of a volatile component (Kovaleva et al., 2018).

Granophyre Dikes are composed of orthopyroxene laths enclosed within a fibrous or micropegmatitic plagioclase-orthoclase-quartz matrix. Accessory minerals are clinopyroxene, biotite, ilmenite, zircon, apatite, spinel, and magnetite. Amphibole, biotite, and chlorite are retrograde products replacing orthopyroxene (Therriault et al., 1996; Kovaleva et al., 2018). Petrographic examination demonstrated that dikes in the core are texturally distinct from those found at the corecollar boundary (Therriault et al., 1996, 1997; French and Nielsen,

A)

\section{Distance (m)}

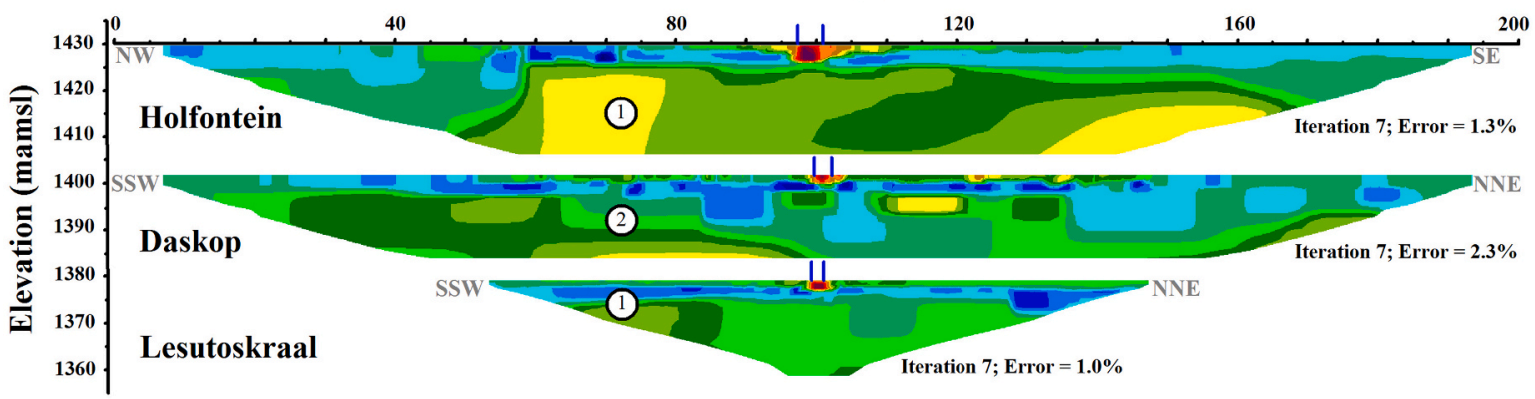

B)

Distance (m)

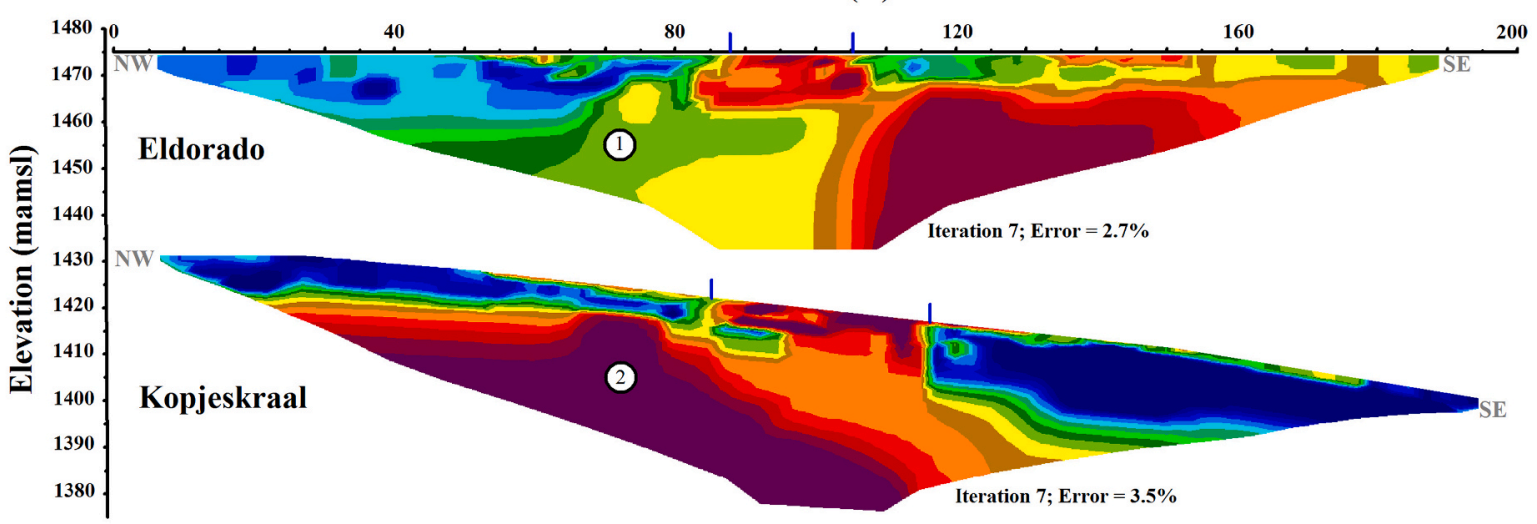

Resistivity color scales:

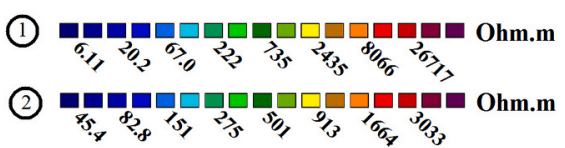

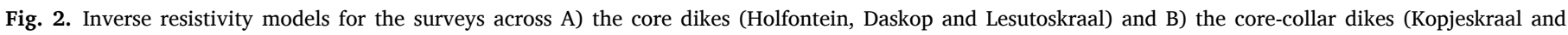

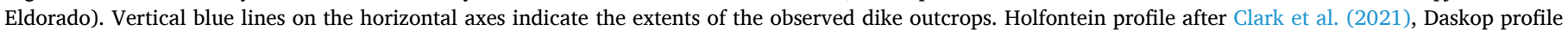
after Fourie et al. (2019). (For interpretation of the references to color in this figure legend, the reader is referred to the web version of this article.) 
1990).

\section{Methods}

Five Granophyre Dikes, the Kopjeskraal (1420 mamsl) and Eldorado (1475 mamsl), located at the core-collar boundary, and the Daskop (1402 mamsl), Lesutoskraal (1380 mamsl) and Holfontein (1430 mamsl), located in the core (Fig. 1B), were investigated by twodimensional (2D) electrical resistivity tomography (ERT). The Kopjeskraal and Eldorado dikes correspond to dike 7 and dike 8, respectively, and the Holfontein, Lesutoskraal, and Daskop dikes correspond respectively to dikes 1,3 , and 4 as numbered by Therriault et al. (1996) (Fig. 2B).

Fourteen samples from the core-collar dikes and 11 samples from the core dikes were analyzed with X-ray fluorescence (XRF) for bulk chemical composition. For the details of the XRF methodology, see Kovaleva et al. (2018).

The ERT survey lines were laid out perpendicular to the strikes of the dikes and centered on the dike outcrops. The Lund Imaging System (Terrameter SAS1000, Electrode Selector ES10-64C and multicore cables) supplied by Guideline Geo AB was used for the field surveys. Unit electrode spacings of $2.5 \mathrm{~m}$ were used for all surveys, except at Lesutoskraal, where a smaller spacing of $1.25 \mathrm{~m}$ was employed to obtain data at a higher spatial density. A total of 81 electrodes were used at each site, giving line lengths of $100 \mathrm{~m}$ at Lesutoskraal and $200 \mathrm{~m}$ at the other dikes. All surveys were conducted with the Wenner-Schlumberger electrode array, which is a modified Schlumberger array in which the separations between the current electrodes are multiples of the separations between the potential electrodes. The Wenner-Schlumberger array is moderately sensitive to both horizontal and vertical structures, and is considered to be a good compromise between the Wenner array (sensitive to horizontal structures) and the dipole-dipole array (sensitive to vertical structures) when attempting to resolve both vertical and lateral resistivity changes in the subsurface (Loke, 2020).

Two-dimensional models of the subsurface resistivity distribution were obtained through inverse modeling. The software package Res2DInv, developed by Geotomo Software Sdn Bhd, was used to invert the apparent resistivity data recorded during the ERT surveys. An inversion algorithm using the $\mathrm{L} 1$ norm was employed to produce inverse resistivity models with sharp boundaries between units of different resistivities.

\section{Results}

\subsection{Geophysical surveys}

The 2D resistivity models obtained for the Granophyre Dikes are distinctly different between the core-collar dikes and the core dikes (Fig. 2).

\subsubsection{Core dikes}

Although variations in the resistivities of the basement rocks are observed in the 2D resistivity models of the core dikes (Fig. 2A), these resistivity models show three distinct horizons of the host rocks: a thin $(<5 \mathrm{~m})$ near-surface horizon of moderate resistivities (a few hundred $\Omega \mathrm{m}$ ), underlain by a more conductive horizon (resistivities of tens to hundreds of $\Omega \mathrm{m}$ ), followed by more resistive material (a few hundred $\Omega \mathrm{m})$ at depth. Shallow zones of high resistivity that spatially coincide with the occurrence of Granophyre Dike outcrops are observed at the centers of the resistivity models. These zones are only a few meters wide, similar to the widths of the dike outcrops, and are interpreted to be due to the presence of the Granophyre Dike material. The high-resistivity zones do not extend deeper than $5 \mathrm{~m}$ into the subsurface, suggesting small depth extents for the core dikes. For better visualization of the core dikes, the resistivity models for the central $100 \mathrm{~m}$ of the profiles only are provided in Supplementary Fig. 1.
Although the dike resistivities are orders of magnitude higher than the resistivities of the host rock, there is also a large variation between the individual dikes. The maximum modeled resistivities for the Holfontein and Lesutoskraal dikes exceed 34,000 $\Omega \mathrm{m}$, while the maximum modeled resistivity for the Daskop dike is only $3775 \Omega \mathrm{m}$. For this reason, different logarithmic color scales are used to display the different resistivity models in Fig. 2A. The cause of the large variation in dike resistivities is currently unknown. More details on Daskop and Holfontein dikes can be found in Fourie et al. (2019) and Clark et al. (2021), respectively.

\subsubsection{Core-collar dikes}

In contrast to the core dikes, the resistivity models for the core-collar dikes reveal broader zones of high resistivities that extend deeper into the crust. As with the core dikes, the maximum resistivities of the two core-collar dikes differ by an order of magnitude, necessitating different logarithmic color scales in the resistivity models to show the contrasts between the dikes and their host rocks (Fig. 2B). As compared to the core dikes, the profile across the Kopjeskraal dike reveals a much broader zone $(\sim 35 \mathrm{~m}$ wide) of high resistivities $(\sim 4000 \Omega \mathrm{m})$ at shallow depth. The width of this zone corresponds to the thickness of the dike outcrop. However, the resistivity model indicates that the true dike thickness is smaller than the width of the outcrop; below a depth of $\sim 5 \mathrm{~m}$ below ground level (mbgl), the thickness of the dike reduces to $\sim 20 \mathrm{~m}$. The resistivity of the dike decreases below this depth but remains above $1400 \Omega \mathrm{m}$. The profile across the Eldorado dike (Fig. 2B) also reveals a broad zone ( $\sim 18 \mathrm{~m}$ wide) of high resistivities (maximum $\sim 30,000 \Omega \mathrm{m}$ ) at shallow depth. This thickness of the dike is retained at depth, until it reaches an apparently horizontal lowermost terminus at a depth of $\sim 10$ $\mathrm{m}$ (see next section for discussion on depth profiles).

The respective zones of high resistivities associated with both the Kopjeskraal and Eldorado dikes extend to greater depths than any of the core dikes by at least $5 \mathrm{~m}$. The full depth extent of the Kopjeskraal dike cannot, however, be established from the resistivity model due to the presence of other high-resistivity material at depth, which masks the presence of the dike. Nevertheless, the depth extent of the dike is at least $12 \mathrm{~m}$, as observed at the southeastern contact between the dike and the low-resistivity host rock (near position $115 \mathrm{~m}$ in Fig. 2B).

\subsubsection{Depth profiles through the core and core-collar dikes}

Depth profiles of the modeled resistivities for all five surveyed dikes are shown in Fig. 3, which displays the modeled resistivities near the centers of the dikes, normalized with respect to their maximum values, from ground level to $20 \mathrm{mbgl}$. The maximum modeled values are also shown as multipliers for each depth profile. The depth profiles of the core dikes (solid lines) in Fig. 3 all display near-surface maxima, followed by abrupt reductions in resistivity at depths ranging between $\sim 2$ mbgl (Daskop) and $\sim 4 \mathrm{mbgl}$ (Holfontein). The reductions in resistivity are up to two orders of magnitude (Daskop: $3775 \Omega \mathrm{m}$ to $320 \Omega \mathrm{m}$; Holfontein: $48,804 \Omega \mathrm{m}$ to $568 \Omega \mathrm{m}$; Lesutoskraal: $34,267 \Omega \mathrm{m}$ to $99 \Omega \mathrm{m}$ ).

The depth profile of the Kopjeskraal dike is dissimilar to the profiles of the core dikes as it reaches a maximum resistivity $(3780 \Omega \mathrm{m})$ at a depth of 4-6 mbgl, before it shows an abrupt decrease to $\sim 47 \%$ of its maximum value. Below that, the resistivity gradually decreases with depth until it stabilizes at a value of $\sim 40 \%$ of its maximum. The highresistivity $(>1400 \Omega \mathrm{m})$ material below a depth of $\sim 7 \mathrm{mbgl}$ suggests that the dike extends deeper into the subsurface than the core dikes. The depth profile of the Eldorado dike displays an abrupt decrease in resistivity in the first two meters, but retains a value of between $\sim 40 \%$ and $\sim 60 \%$ of its maximum value up to a depth of $\sim 9 \mathrm{~m}$, after which another sharp decrease in resistivities is observed. The presence of highresistivity material to a depth of $\sim 9 \mathrm{~m}$ indicates that Eldorado dike extends to at least this depth. 


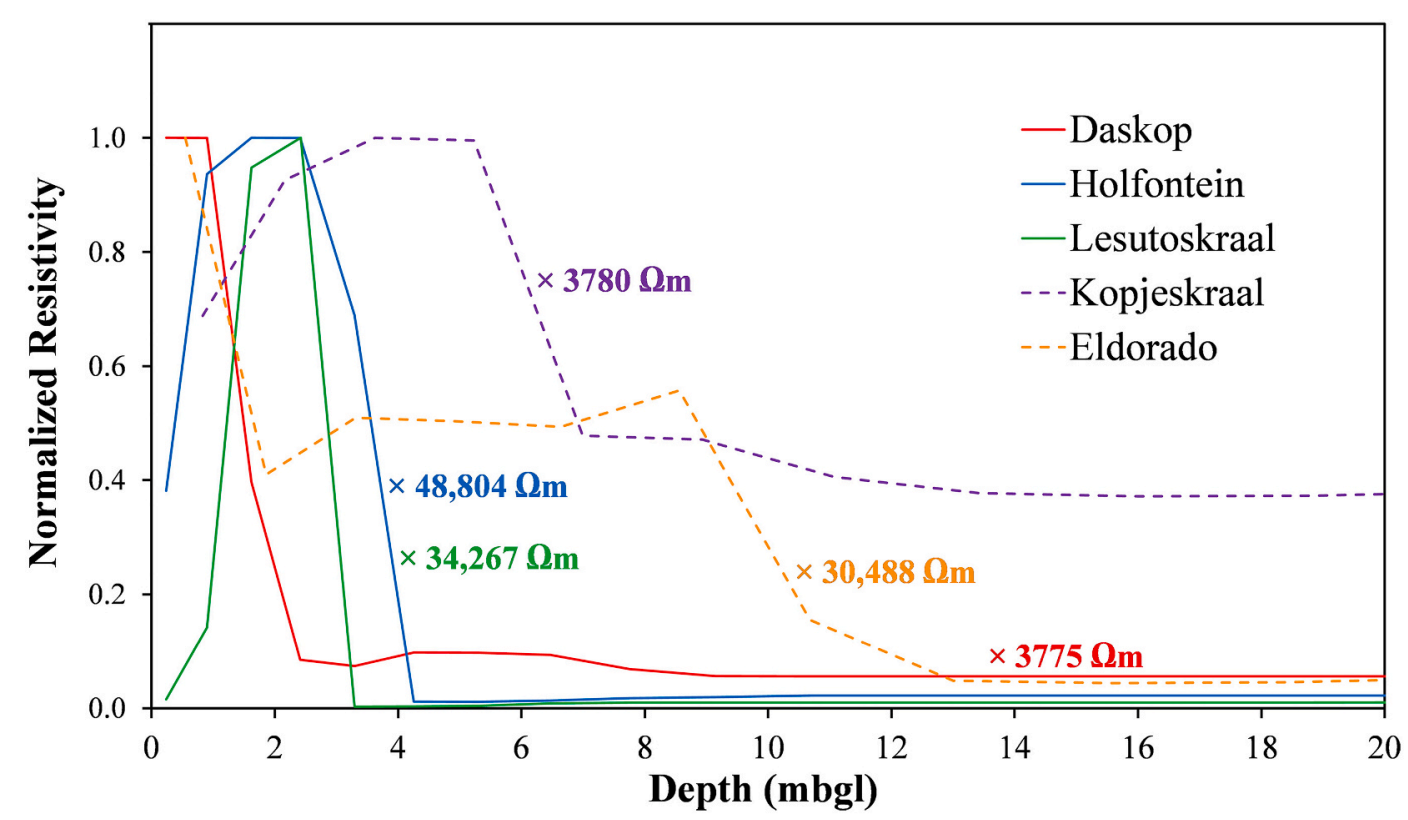

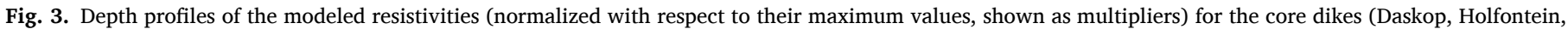
Lesutoskraal; solid lines) and core-collar dikes (Kopjeskraal, Eldorado, dashed lines).

\subsection{Bulk geochemical composition of the dikes}

The major element compositions of the Daskop, Lesutoskraal and Holfontein Granophyre Dikes are consistent with previously published geochemical data (Fig. 4; Table 1). The Kopjeskraal Granophyre Dike

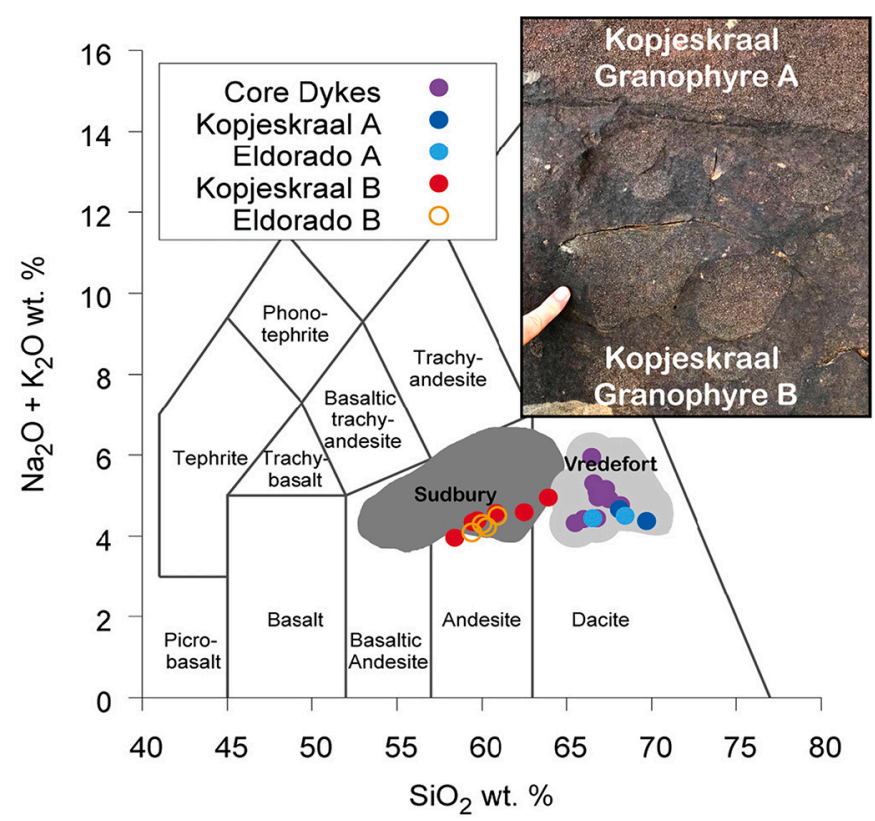

Fig. 4. Total alkali and silica diagram of Granophyre Dike analyses (Le Maitre et al., 2002). The core dikes, Kopjeskraal Granophyre A (KGA), and Eldorado A (EDA) are indistinguishable from published results for Vredefort Granophyre Dikes, but the compositions of Kopjeskraal Granophyre B (KGB) and Eldorado B (EDB) are similar to the Sudbury Offset Dikes. Fields with compositional data for Sudbury Offset Dikes ("Sudbury"; dark grey; data from Lightfoot et al., 1997, Hecht et al., 2008, and Pilles et al., 2017; $n=162$ ) and Vredefort Granophyre Dikes ("Vredefort"; light grey; data from Willemse, 1937, Therriault et al., 1997, and Kovaleva et al., 2018; Huber et al., 2020; $n=41$ ). Inset after Huber et al. (2020), shows field photograph of KGA and KGB contact, with clasts of KGA captured by KGB. Finger for scale. contains two distinct textural and geochemical phases (Fig. 4, inset): the Kopjeskraal Granophyre A (KGA) and the Kopjeskraal Granophyre B (KGB) (Huber et al., 2020). KGA is observed at the dike's margins, contains lithic clasts, and compositionally and texturally is indistinguishable from the core dikes. In the central part of the dike, approximately $4 \mathrm{~m}$ from, and parallel to, the contact with the host granite, a fine-grained, dark phase of the Granophyre Dike is present (KGB). KGB has sharp contact with the surrounding KGA and contains rounded inclusions of the KGA, up to $5 \mathrm{~cm}$ in diameter (Fig. 4, inset). Geochemically, the KGB is distinct from other Granophyre Dike compositions. Both major (Fig. 4; Le Bas et al., 1986) and trace element (Fig. 5; Winchester and Floyd, 1977) classifications show that the KGA and core dike samples measured in this study are dacitic. However, the major element compositions of the KGB samples plot in the andesitic field, and the trace element composition of the KGB is andesitic to dacitic. In both classification schemes, the KGB is significantly more mafic than other Granophyre Dike samples. Similarly, the Eldorado dike has at least two phases (EDA and EDB). The EDA is a marginal phase that is geochemically identical to the core dikes and the KGA, whereas the interior EDB phase is more mafic (Fig. 4).

The trace elemental compositions of the Granophyre Dikes are similar (Fig. 6A), and are consistent with a common origin of all Granophyre Dikes at Vredefort and broadly similar to the Sudbury Offset Dikes (Huber et al., 2020). The KGA and EDA have a nearly identical trace element composition to the core dikes (Fig. 6B), but the KGB and EDB are comparatively depleted in $\mathrm{Rb}$, Th, and $\mathrm{Zr}$ and enriched in $\mathrm{P}$ and $\mathrm{Ti}$ with respect to the core dikes.

\section{Discussion}

\subsection{Modeling and interpretation of geophysical data}

\subsubsection{Host rocks and depth extents of core dikes}

The lithological and structural complexities of the basement rocks at the Vredefort impact structure are well known (e.g., Hart et al., 1990, 1999; Lana et al., 2004; Fourie et al., 2019), and are confirmed by the resistivity models for the core dikes that display large variations in the resistivities of the host rock (Fig. 2A). Although the most straightforward interpretation of the abrupt decreases in the resistivities with depth at the core dikes is that the dikes have limited depth extents (as in Fourie 
Table 1

XRF results of core and collar granophyre dykes.

\begin{tabular}{|c|c|c|c|c|c|c|c|c|c|c|c|c|c|}
\hline & & \multicolumn{11}{|l|}{ Core Dikes } & \multirow{3}{*}{$\frac{\frac{\text { Collar Dikes }}{\text { Kopjeskraal A }}}{\text { KGA18-03 }}$} \\
\hline & & \multicolumn{3}{|l|}{ Daskop } & \multicolumn{6}{|l|}{ Holfontein } & \multicolumn{2}{|l|}{ Lesutoskraal } & \\
\hline & & DGP16-01 & DGP16-05 & DGP16-08 & HGP18-15 & HGP18-16 & HGP18-17 & HGP18-18 & HGP18-19 & HGP18-20 & LGP19-01A & LGP19-01B & \\
\hline $\mathrm{SiO}_{2}$ & $(w t \%)$ & 66.5 & 68.2 & 66.8 & 66.6 & 67.1 & 66.8 & 67.3 & 66.9 & 67.5 & 65.5 & 66.0 & 68.1 \\
\hline $\mathrm{TiO}_{2}$ & $(w t \%)$ & 0.77 & 0.51 & 0.49 & 0.50 & 0.46 & 0.49 & 0.47 & 0.47 & 0.48 & 0.52 & 0.52 & 0.50 \\
\hline $\mathrm{Al}_{2} \mathrm{O}_{3}$ & $(w t \%)$ & 14.5 & 12.4 & 12.4 & 12.6 & 12.5 & 12.6 & 12.6 & 12.7 & 12.6 & 12.4 & 12.6 & 12.2 \\
\hline $\mathrm{Fe}_{2} \mathrm{O}_{3}$ & $(w t \%)$ & 5.63 & 7.14 & 7.20 & 7.14 & 6.95 & 7.12 & 6.95 & 7.08 & 6.99 & 7.49 & 7.51 & 7.19 \\
\hline $\mathrm{CaO}$ & $(w t \%)$ & 3.43 & 3.46 & 3.41 & 3.67 & 3.50 & 3.62 & 3.45 & 3.58 & 3.53 & 3.80 & 3.85 & 3.87 \\
\hline $\mathrm{MgO}$ & $(w t \%)$ & 1.57 & 3.39 & 3.26 & 3.77 & 3.57 & 3.33 & 3.43 & 3.56 & 3.52 & 3.65 & 3.50 & 3.42 \\
\hline $\mathrm{MnO}$ & $(w t \%)$ & 0.06 & 0.14 & 0.13 & 0.14 & 0.14 & 0.14 & 0.13 & 0.14 & 0.13 & 0.14 & 0.14 & 0.14 \\
\hline $\mathrm{K}_{2} \mathrm{O}$ & $(w t \%)$ & 2.42 & 2.05 & 2.10 & 2.31 & 2.31 & 2.34 & 2.33 & 2.34 & 2.38 & 1.84 & 1.88 & 2.08 \\
\hline $\mathrm{Na}_{2} \mathrm{O}$ & (wt\%) & 3.53 & 2.71 & 2.34 & 2.99 & 2.67 & 2.75 & 2.83 & 2.61 & 2.53 & 2.48 & 2.54 & 2.58 \\
\hline $\mathrm{P}_{2} \mathrm{O}_{5}$ & $(w t \%)$ & 0.19 & 0.10 & 0.10 & 0.10 & 0.09 & 0.10 & 0.09 & 0.10 & 0.10 & 0.12 & 0.12 & 0.10 \\
\hline LOI & $(w t \%)$ & 0.81 & 0.18 & 0.05 & 0.01 & 0.07 & 0.01 & N.D. & N.D. & N.D. & 0.09 & 0.19 & N.D. \\
\hline Total & (wt\%) & 99.4 & 100.2 & 98.3 & 99.8 & 99.3 & 99.3 & 98.9 & 99.3 & 99.7 & 98.0 & 98.8 & 100.2 \\
\hline Sc & $(\mathrm{ppm})$ & 13 & 21 & 21 & 17 & 15 & 15 & 17 & 20 & 19 & 2 & 7 & 14 \\
\hline $\mathrm{V}$ & $(\mathrm{ppm})$ & 82 & 94 & 90 & 85 & 83 & 84 & 85 & 85 & 84 & 19 & 31 & 89 \\
\hline $\mathrm{Cr}$ & (ppm) & 39 & 241 & 272 & 235 & 240 & 244 & 259 & 254 & 255 & 67 & 120 & 232 \\
\hline Co & $(\mathrm{ppm})$ & 20 & 31 & 28 & 27 & 28 & 26 & 25 & 27 & 26 & 29 & 30 & 27 \\
\hline $\mathrm{Ba}$ & (ppm) & 767 & 480 & 485 & 473 & 458 & 452 & 467 & 458 & 468 & 75 & 220 & 478 \\
\hline $\mathrm{Ni}$ & $(\mathrm{ppm})$ & 33 & 125 & 123 & 115 & 123 & 117 & 124 & 121 & 119 & 132 & 134 & 117 \\
\hline $\mathrm{Cu}$ & $(\mathrm{ppm})$ & 41 & 65 & 58 & 54 & 51 & 53 & 57 & 54 & 52 & 77 & 65 & 57 \\
\hline $\mathrm{Zn}$ & (ppm) & 107 & 67 & 58 & 61 & 69 & 56 & 66 & 60 & 59 & 62 & 72 & 54 \\
\hline $\mathrm{Rb}$ & (ppm) & 55 & 57 & 58 & 67 & 67 & 68 & 68 & 67 & 67 & 57 & 58 & 59 \\
\hline $\mathrm{Sr}$ & (ppm) & 499 & 261 & 268 & 252 & 247 & 251 & 254 & 255 & 257 & 207 & 209 & 245 \\
\hline $\mathrm{Y}$ & $(\mathrm{ppm})$ & 19 & 17 & 16 & 16 & 17 & 16 & 16 & 16 & 16 & 14 & 14 & 17 \\
\hline $\mathrm{Zr}$ & $(\mathrm{ppm})$ & 206 & 143 & 142 & 143 & 142 & 143 & 145 & 144 & 144 & 133 & 134 & 133 \\
\hline $\mathrm{Nb}$ & $(\mathrm{ppm})$ & 8 & 7 & 6 & 7 & 7 & 7 & 7 & 7 & 7 & 7 & 8 & 6 \\
\hline Mo & $(\mathrm{ppm})$ & 2 & 3 & 2 & 3 & 3 & 2 & 4 & 2 & 2 & N.D. & N.D. & 2 \\
\hline $\mathrm{Pb}$ & $(\mathrm{ppm})$ & 9 & 10 & 10 & 12 & 11 & 11 & 13 & 12 & 14 & 12 & 11 & 12 \\
\hline Th & (ppm) & 8 & 6 & 6 & 7 & 7 & 7 & 6 & 8 & 6 & 7 & 6 & 4 \\
\hline $\mathrm{U}$ & (ppm) & 2 & N.D. & N.D. & 2 & N.D. & N.D. & 3 & N.D. & N.D. & N.D. & N.D. & N.D. \\
\hline
\end{tabular}

N.D. = not detected.

et al., 2019), another conceivable explanation of such reductions could be the presence of groundwater, as small changes in the water content within a rock may lead to resistivity changes (Telford et al., 1990; Glover, 2015). The observed low-resistivity horizons in Fig. 2A and Supplementary Fig. 1 may be due to the presence of groundwater. A hydrocensus conducted in 2007 found that the water table in the study area occurred between 2 and $4 \mathrm{mbgl}$ (Pretorius, 2009; Van der Walt et al., 2010), although the water table was likely deeper at the time of the ERT surveys of the current study due to the five years of drought in South Africa that preceded the survey. However, while groundwater can be expected to decrease the measured resistivities of the dikes, increased saturation alone would not cause the dike material to become indistinguishable from the host rocks, as groundwater would also reduce the resistivities of the host rocks.

In the shallow subsurface, the Granophyre Dikes are orders of magnitude more resistive than the host rocks, and there is no plausible explanation for why this contrast would disappear at depth below the groundwater table. It is also highly improbable that groundwater could coincidentally reduce the resistivities of all three core dikes, each having different resistivity contrast to their host rocks in the shallow subsurface, to such an extent that they become indistinguishable from their host rocks at depth. Furthermore, the inverse resistivity model for the Holfontein Dike (Fig. 2A and Supplementary Fig. 1) shows that the highresistivity zone associated with the dike extends well within the horizon of low resistivities, inconsistent with the hypothesis that the resistivity contrast between the dike and its host rock would disappear due to the presence of groundwater. Therefore, the observed shallow depth extent of the highly resistive dike material cannot be attributed to groundwater.

\subsubsection{Depth extent modeling}

Another possible explanation for the apparent shallow depth extents of the core dikes is that the inversion algorithm converged on similar false solutions for all three core dikes. To investigate this possibility, numerical models were constructed to represent dikes of different depth extents, ranging from $2 \mathrm{~m}$ to $50 \mathrm{~m}$. The dikes were assigned thicknesses of $2.5 \mathrm{~m}$, similar to the measured outcrop widths of the core dikes at the positions of the ERT profiles, and resistivities of $2000 \Omega \mathrm{m}$, an order of magnitude higher than the resistivity of the host rock $(200 \Omega \mathrm{m})$. Forward modeling was done using the software package Res2DMod, developed by Geotomo Software Sdn Bhd, to calculate the responses that could be expected from such dikes, using the same electrode configuration as was used for the field surveys across the core dikes to attain comparable resolution. Finally, the calculated responses were subjected to the same inversion procedure as the field data recorded across the core-collar and core dikes.

The results of these numerical models show that the dikes with shallow depth extents $(2 \mathrm{~m}, 3 \mathrm{~m}$, and $5 \mathrm{~m}$ ) are accurately reproduced (Fig. 7), displaying abrupt decreases in resistivity at depths approximately equal to the depth extents of the dikes (Fig. 8), and are similar to the depth profiles of the core dikes in Fig. 3. In contrast, the depth profiles for the modeled dikes with larger depth extents of 15 and $50 \mathrm{~m}$ display gradual resistivity decreases, before flattening out on resistivity values equal to $\sim 0.1$ and $\sim 0.2$ of the maximum values for each profile. These profiles do not define sharp lower boundaries corresponding to the depth extents of the modeled dikes. Furthermore, the gradual reductions in modeled resistivities occur over depth intervals that are smaller than the true depth extents of the modeled dikes, incorrectly suggesting smaller depth extents for these dikes. However, these depth intervals are notably larger than the modeled depth extents of the core dikes (Fig. 2A). Therefore, the numerical modeling confirms that the observed shallow depth extent of the highly resistive material most likely represents the true depth extent of the Granophyre Dikes.

The results of the numerical modeling thus show that the shallow depth extents observed for the core dikes are unlikely to represent false solutions due to the inherent non-uniqueness of the inversion process. Although the depth extents of the dikes with large penetration depths may be underestimated by the modeling process, such dikes cannot 


\begin{tabular}{|c|c|c|c|c|c|c|c|c|c|c|c|c|c|c|}
\hline \multicolumn{15}{|l|}{ Collar Dikes } \\
\hline \multirow{2}{*}{$\frac{\text { Kopjeskraal A }}{\text { KGA18-04 }}$} & \multicolumn{6}{|c|}{ Kopjeskraal B } & \multicolumn{2}{|l|}{ Eldorado A } & \multicolumn{6}{|l|}{ Eldorado B } \\
\hline & KGB18-01 & KGB18-02 & KGP18-05 & KGB18-V & KGB-i & KGB-ii & ELD GA1 i & ELD GA1 ii & ELD GA2 i & ELD GA2 ii & ELD GA2 iii & ELD GB i & ELD GB ii & ELD GB iii \\
\hline 69.7 & 58.4 & 63.9 & 62.5 & 59.5 & 59.7 & 60.9 & 66.5 & 68.4 & 61.1 & 60.9 & 60.3 & 60.5 & 60.0 & 59.4 \\
\hline 0.50 & 0.54 & 0.59 & 0.64 & 0.61 & 0.67 & 0.68 & 0.52 & 0.54 & 0.64 & 0.65 & 0.65 & 0.62 & 0.61 & 0.61 \\
\hline 11.8 & 13.2 & 12.7 & 13.0 & 13.3 & 13.1 & 13.4 & 12.4 & 12.6 & 13.5 & 13.4 & 13.2 & 13.5 & 13.4 & 13.3 \\
\hline 7.15 & 10.5 & 8.50 & 9.71 & 10.3 & 9.70 & 10.0 & 7.30 & 7.50 & 9.90 & 9.90 & 9.90 & 10.1 & 10.0 & 9.90 \\
\hline 3.63 & 6.91 & 5.01 & 5.85 & 6.77 & 5.96 & 6.10 & 3.88 & 3.97 & 6.19 & 6.20 & 6.13 & 6.60 & 6.54 & 6.50 \\
\hline 3.31 & 5.81 & 3.95 & 4.12 & 5.21 & 4.28 & 4.49 & 3.65 & 3.64 & 4.26 & 4.29 & 4.23 & 4.79 & 4.81 & 4.75 \\
\hline 0.13 & 0.17 & 0.14 & 0.16 & 0.16 & 0.16 & 0.16 & 0.14 & 0.14 & 0.16 & 0.15 & 0.16 & 0.16 & 0.16 & 0.15 \\
\hline 2.01 & 1.34 & 1.94 & 1.79 & 1.51 & 1.74 & 1.75 & 2.03 & 2.09 & 1.73 & 1.74 & 1.74 & 1.58 & 1.57 & 1.57 \\
\hline 2.36 & 2.62 & 3.01 & 2.80 & 2.83 & 2.65 & 2.82 & 2.41 & 2.41 & 2.68 & 2.76 & 2.48 & 2.72 & 2.73 & 2.52 \\
\hline 0.09 & 0.09 & 0.11 & 0.13 & 0.11 & 0.13 & 0.13 & 0.11 & 0.11 & 0.13 & 0.12 & 0.12 & 0.12 & 0.12 & 0.12 \\
\hline N.D. & N.D. & N.D. & 0.04 & 0.07 & 0.03 & 0.02 & -0.02 & 0.02 & -0.01 & 0.07 & -0.01 & -0.04 & N.D. & -0.01 \\
\hline 100.6 & 99.5 & 99.9 & 100.8 & 100.3 & 98.1 & 100.3 & 98.9 & 101.5 & 100.3 & 100.2 & 98.8 & 100.5 & 99.9 & 98.7 \\
\hline 20 & 16 & 12 & 17 & 25 & 21 & 19 & 13 & 14 & 19 & 21 & 17 & 21 & 21 & 21 \\
\hline 88 & 141 & 112 & 135 & 146 & 162 & 163 & 107 & 96 & 151 & 146 & 144 & 155 & 154 & 154 \\
\hline 241 & 239 & 183 & 165 & 186 & 162 & 166 & 250 & 232 & 149 & 145 & 137 & 239 & 219 & 205 \\
\hline 28 & 42 & 32 & 34 & 39 & 39 & 39 & 30 & 31 & 37 & 37 & 36 & 40 & 39 & 39 \\
\hline 459 & 302 & 430 & 381 & 337 & 375 & 374 & 484 & 463 & 386 & 362 & 384 & 344 & 337 & 353 \\
\hline 121 & 136 & 113 & 96 & 112 & 95 & 101 & 112 & 102 & 88 & 80 & 76 & 107 & 103 & 100 \\
\hline 57 & 66 & 62 & 63 & 70 & 55 & 59 & 43 & 39 & 54 & 52 & 50 & 59 & 54 & 55 \\
\hline 63 & 73 & 60 & 75 & 82 & 75 & 78 & 60 & 56 & 77 & 74 & 71 & 80 & 78 & 74 \\
\hline 56 & 34 & 52 & 47 & 39 & 55 & 57 & 68 & 65 & 59 & 57 & 56 & 56 & 53 & 52 \\
\hline 232 & 194 & 224 & 207 & 195 & 206 & 209 & 239 & 226 & 220 & 215 & 214 & 220 & 208 & 204 \\
\hline 17 & 16 & 18 & 19 & 18 & 20 & 21 & 16 & 15 & 20 & 19 & 19 & 19 & 19 & 18 \\
\hline 132 & 91 & 124 & 116 & 102 & 140 & 142 & 160 & 152 & 143 & 138 & 139 & 138 & 130 & 128 \\
\hline 6 & 5 & 6 & 6 & 5 & 7 & 7 & 7 & 6 & 7 & 7 & 6 & 7 & 7 & 6 \\
\hline 2 & 2 & 2 & 2 & 2 & 1 & N.D. & N.D. & 3 & 1 & N.D. & 1 & N.D. & N.D. & 2 \\
\hline 11 & 5 & 9 & 8 & 5 & 16 & 20 & 24 & 24 & 25 & 20 & 20 & 27 & N.D. & 19 \\
\hline 6 & 3 & 4 & 5 & 4 & 4 & 3 & 3 & 3 & 4 & 3 & 2 & 2 & 4 & 4 \\
\hline N.D. & N.D. & N.D. & N.D. & N.D. & N.D. & N.D. & 2 & N.D. & 3 & N.D. & 3 & 2 & 2 & N.D. \\
\hline
\end{tabular}

cause the resistivity responses observed at the core dikes of this study. The core Granophyre Dikes, therefore, do not extend beyond a few meters below the present erosion surface, confirming the interpretation of Therriault et al. (1996) and Fourie et al. (2019). Notably, this geophysical evidence unequivocally rules out an impact-induced deeper magmatic source of the Granophyre Dikes (i.e., impact-induced volcanic source), as has been suggested for dikes within the lunar Orientale Basin (Andrews-Hanna et al., 2018).

\subsection{Interpretation of geochemical data}

Given the uniform felsic composition of the core dikes, the KGA portion of Kopjeskraal dike, and the EDA portion of the Eldorado dike, these dikes or dike portions must have been derived from a common source (Fig. 4, 6B). The bulk composition of the melt sheet at Vredefort was likely similar to that of the Sudbury and Chicxulub impact melt sheets, as all three shock events were similar in impact energy released and target rock composition, and were large enough to melt and homogenize a portion of the upper continental crust (Kring, 1995; Huber et al., 2020). Because melt entered the fractures from above (i.e., from the melt sheet), the melt that formed the Granophyre Dikes must have been derived from the lowermost portion of the melt sheet at the time of melt extraction (Dietz, 1961; Dence, 1971; Therriault et al., 1996). This inference, along with the felsic composition of the core dikes, KGA, and EDA, indicates that these dikes formed before any chemical differentiation of the impact melt sheet, because melt extracted from the basal portions of the melt sheet after differentiation would have been progressively more mafic (French and Nielsen, 1990; Koeberl et al., 1996; Therriault et al., 1996, 1997; Huber et al., 2020).

Due to their more mafic compositions, the KGB and EDB differ from the other Granophyre Dikes, but are similar in composition to the Offset Dikes at Sudbury (Fig. 4; Huber et al., 2020). The trace element compositions suggest that the KGB and EDB have a common origin with the other dikes, but are derived from a more geochemically evolved melt source, as incompatible elements have been enriched within the KGB and EDB (Fig. 6). The presence of KGA inclusions inside the KGB indicates that the KGA crystallized prior to KGB emplacement and demonstrate that the KGB was emplaced after the KGA portion in the core-collar dikes. Therefore, the mafic compositions of the KGB and EDB

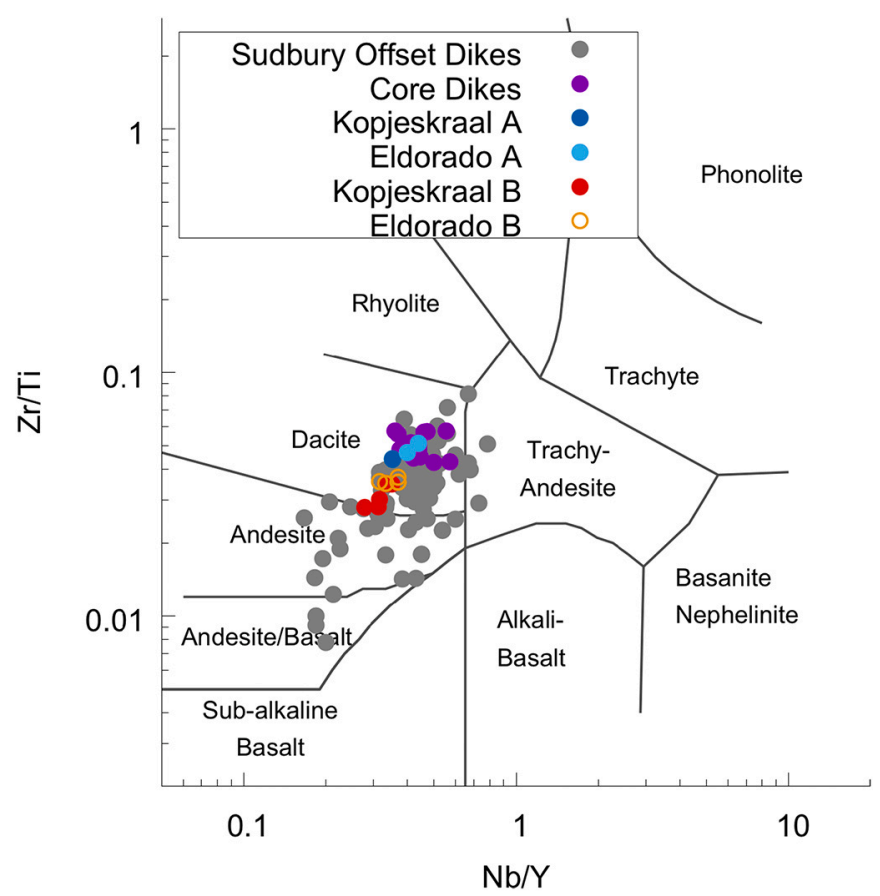

Fig. 5. Classification of the Granophyre Dikes and Offset Dikes using trace elements (Winchester and Floyd, 1977). Data sources for Offset Dikes as in Fig. 4. 


\section{A. Dikes normalized to Vredefort granite}

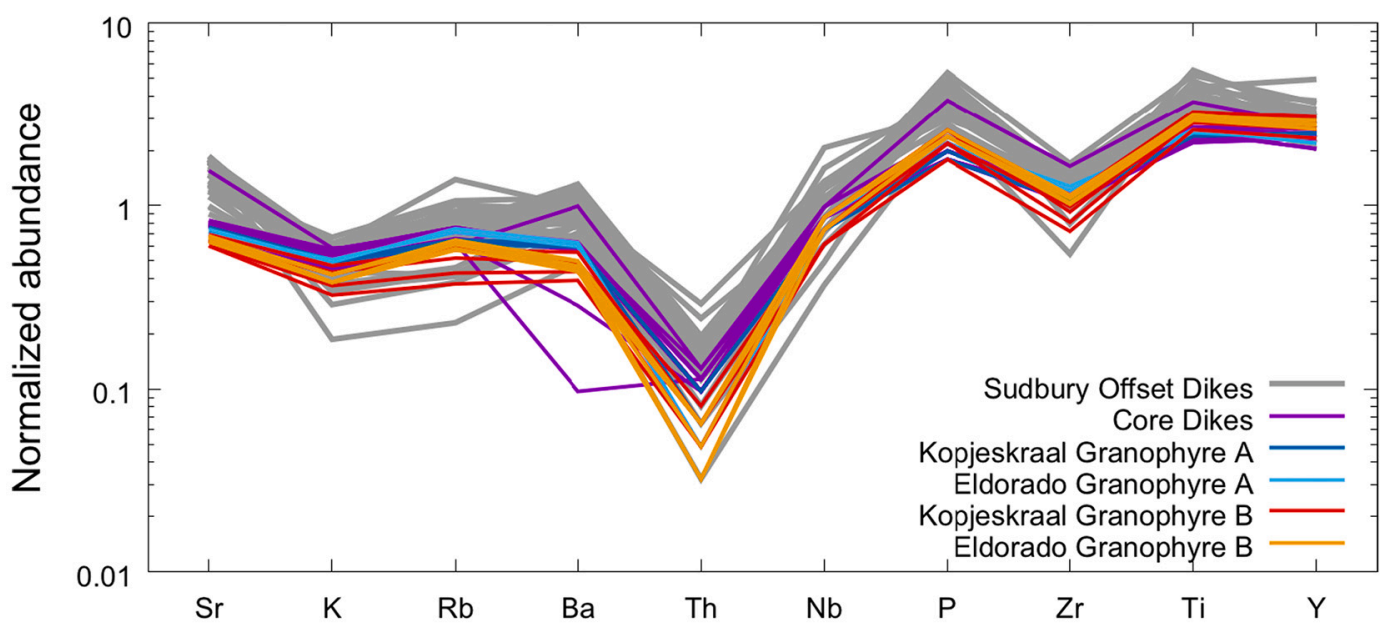

B. Collar dikes normalized to average composition of core dikes

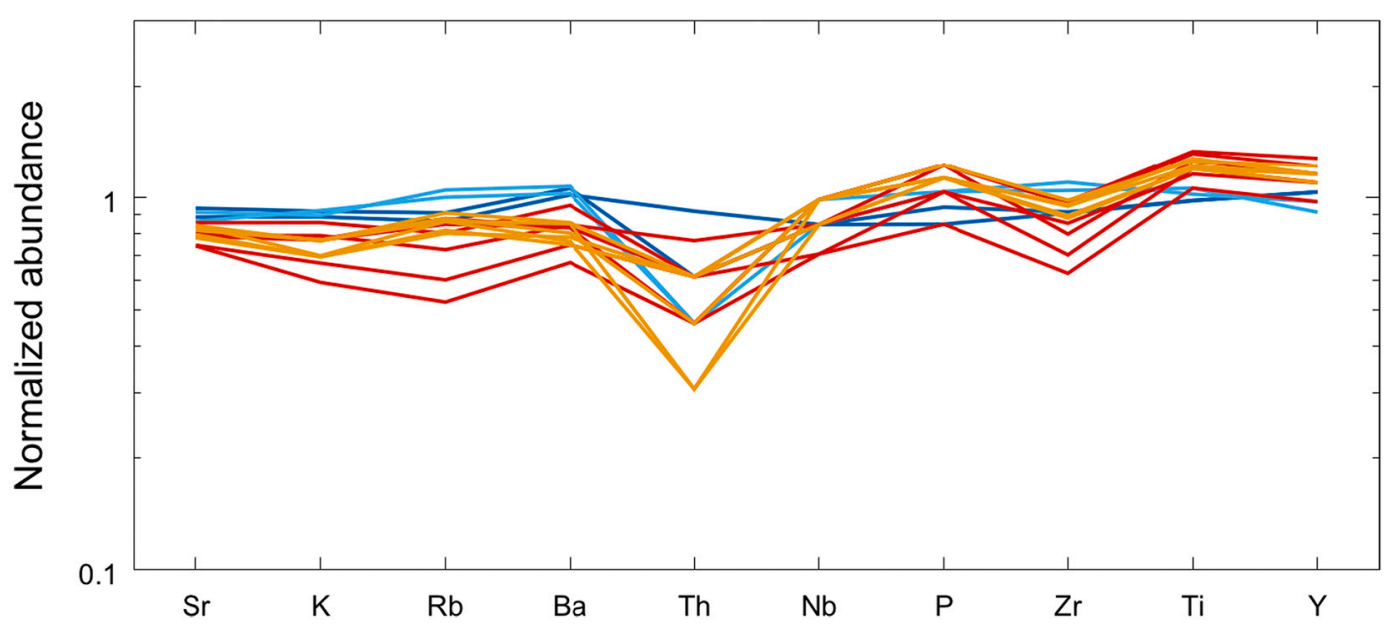

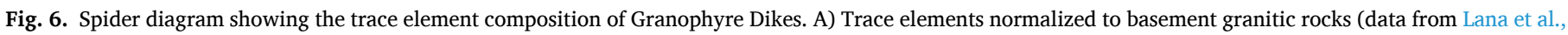

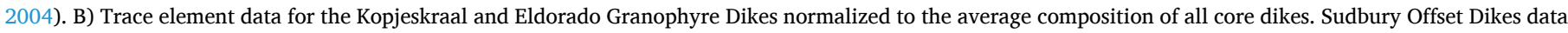
from Pilles et al. (2017).

are best explained by their emplacement after the initial differentiation of the melt sheet, supporting the hypothesis of at least two intrusion pulses (Lieger and Riller, 2012).

It is likely that all of the Granophyre Dikes previously featured multiple phases of melt, but the erosional remnant of the core dikes $(<5$ $\mathrm{m}$ below the surface), as compared to the erosional remnant of the corecollar dikes, ( $\geq 9 \mathrm{~m}$ below the surface), left little evidence of multiple intrusion phases. If so, then later phases of melt may have penetrated through all but the lowermost few $\mathrm{m}$ of melt-filled fractures. Further study will be required to test this hypothesis.

\subsection{Model for the emplacement of impact melt dikes}

Based on recent results of IODP-ICDP Expedition 364, the dynamic collapse model (Fig. 9) for the formation of basin-sized impact craters, such as Vredefort, was recently confirmed (Morgan et al., 2016; Riller et al., 2018; Collins et al., 2020). In this model, impact-induced shock compression and release generates massive amounts of superheated impact melt. Shock-wave induced crustal-scale excavation then produces a bowl-shaped transient cavity (Fig. 9A) lined by impact melt. Subsequently, gravitational instability of the transient cavity causes inward slumping of the cavity wall while the crater center is uplifted (Fig. 9C). Collapse and radial outward displacement of centrally uplifted material over inward-slumped cavity wall segments characterize the terminal phase of crater modification (Fig. 9D). During this phase, target rocks deform via localized decimeter to meter-scale shear faults, in contrast to the earlier, pervasive, grain-scale deformation, suggesting that the cohesive strength of target rock is partially restored during crater modification (Riller et al., 2018). The crater diameter increases until cratering comes to a halt when rock strength reaches a critical level, about ten minutes after impact (Collins et al., 2020).

During the excavation stage (Fig. 9B), a total of approximately $7.5-10.5 \mathrm{~km}$ of crustal material was removed from the impacted area at Vredefort (Elkins-Tanton and Hager, 2005). The shallow depth of the present-day Moho below the Vredefort impact structure $(34 \mathrm{~km})$, compared to the Moho depth in the periphery of the impact structure (39-43 km) (Youssof et al., 2013), approximates the amount of material removed during excavation and the modeled Moho depth at the end of cratering (Fig. 9D). Collectively, these observations indicate that the crust below the crater did not reach isostatic equilibrium at the end of cratering (Rae et al., 2019). Relaxation of the crust must have continued after cratering, albeit at diminished strain rates, and led to upward bending and, thus, horizontal stretching of the upper crust (arrows in Fig. 9D).

Because target rocks regain mechanical strength during the late stages of cratering (Riller et al., 2018), we propose that crustal 


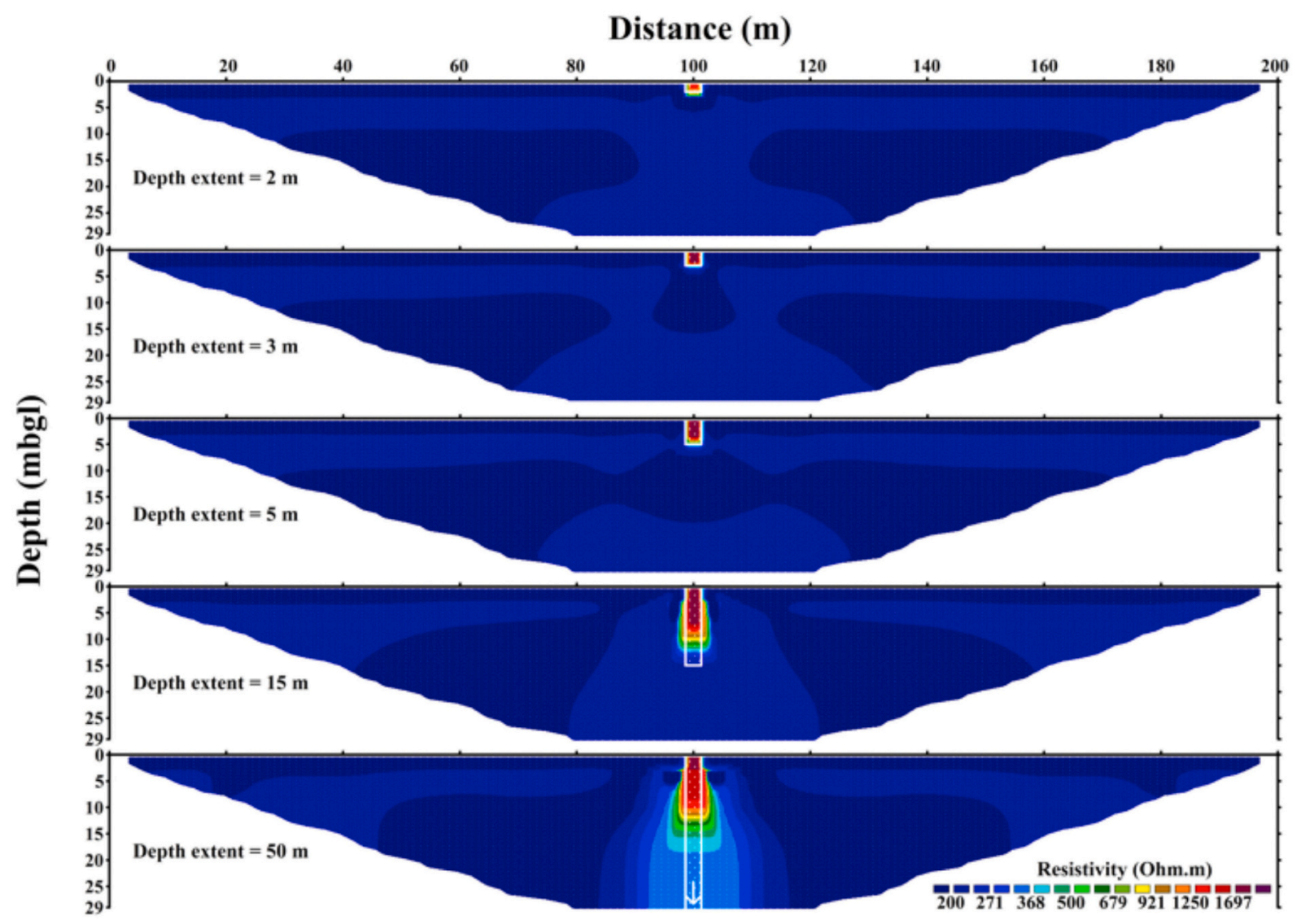

Fig. 7. Modeling results for simulated datasets illustrating the expected inverse resistivity models for hypothetical dikes with depth extents ranging from 2 to $50 \mathrm{~m}$. The simulated dike geometries are shown as white outlines. The results show that for dikes with depth extents $\leq 5$ m, the inverse resistivity models converge on solutions that accurately describe the lowermost boundaries of the dikes.

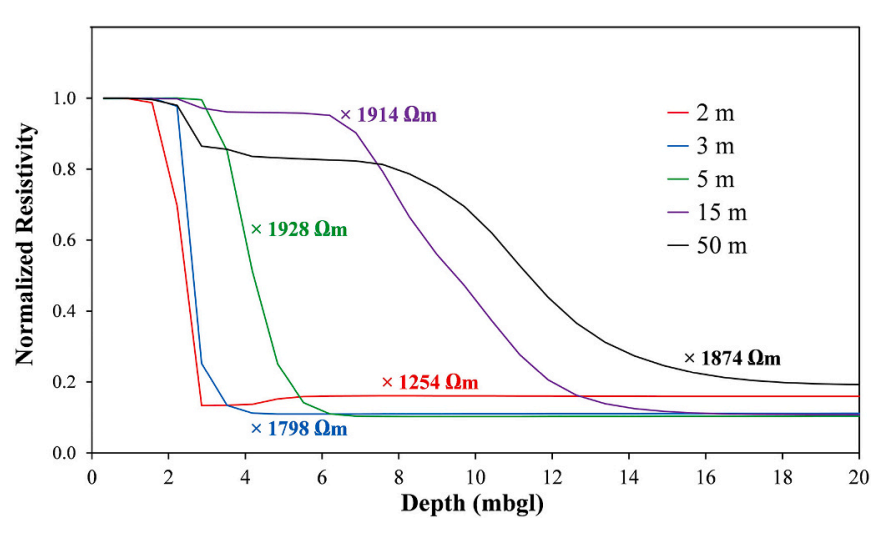

Fig. 8. Depth profiles of the resistivities (normalized with respect to their maximum values, shown as multipliers) for the modeled dikes of different depth extents.

relaxation was likely accompanied by an increase in localization of brittle deformation, particularly within the crust immediately below the crater floor. Continued horizontal stretching of this crust at lower strain rates during crustal relaxation resulted in the formation of sub-vertical extension fractures. Such fractures tapped the impact melt sheet, thus providing a pathway for low-viscosity impact melt to flow downwards, which eventually crystallized to form the Granophyre Dikes. The occurrence of observed dike termini around the present erosion surface may demarcate the maximal depth of dike formation, the crustal level of which corresponds to a kinematic velocity discontinuity (Figs. 9D; 10). Horizontal outward-directed stretching of rock occurred above the discontinuity and formed vertical (melt-filled) fractures, allowing the emplacement of the Granophyre Dikes. In contrast, rock displacements below the velocity discontinuity were characterized by inward-directed displacement of rock below the crater margin and upward-directed, convergent rock flow below the crater center (Fig. 9D). It is likely that dikes formed at various depths, although erosion has removed any direct evidence of such dikes, and the preserved dikes represent the maximum possible depth extent.

Crustal relaxation likely entailed episodic deformation over time, evident by the geochemical variation observed between the core dikes, KGA, and EDA, compared to the KGB and EDB. The composition of the lowermost portion of the melt sheet would change over time, as the initial melt sheet would be near homogeneous, but would likely eventually differentiate so that the felsic fraction would be at the uppermost parts of the melt sheet, and the mafic fraction at the lowermost part of the melt sheet (Fig. 10). The earliest extensional fractures opened at the base of the initial compositionally homogeneous melt sheet, thus forming the KGA, EDA, and core dikes (Fig. 10B). During ongoing crustal relaxation, new fractures formed and preexisting fractures widened, allowing for the emplacement of differentiated, i.e., more mafic melts to be emplaced, such as the KGB and EDB (Fig. 10C). These melts were emplaced alongside, and contain fragments of, the earlier, more felsic melt phases, e.g., the KGA (Fig. 4), suggestive of significant passage of time between their emplacement. The geometry, depth extent and compositional variation of Granophyre Dikes are consistent with a relaxation model of the crust below the Vredefort impact structure taking place over timescales up to $10^{6}$ years (see following section). The crustal instability formed as a direct consequence of the dynamic collapse of the transient cavity (Fig. 9). 

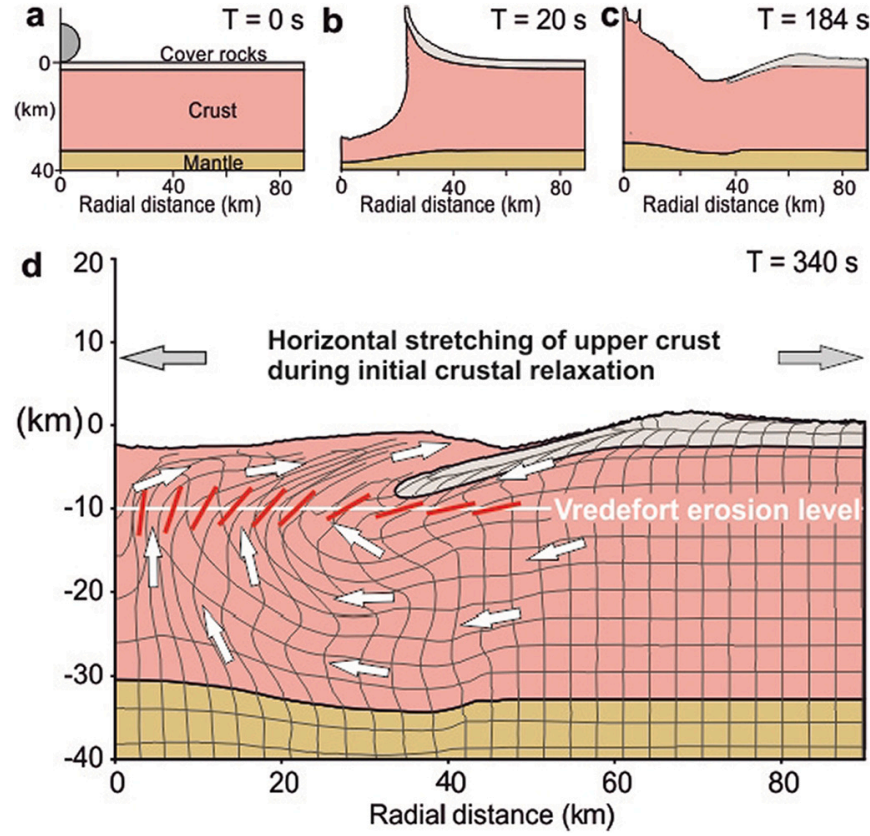

Fig. 9. Schematic diagrams depicting major stages of the dynamic collapse model for peak-ring crater formation, based on numerical modeling (Modified from Riller et al., 2018. see also Collins et al., 2002; Ivanov, 2005; Morgan et al., 2016). T denotes time after impact. (A) Undisturbed configuration of model lithosphere before impact, consisting of sedimentary cover rocks overlying a felsic crust and mantle modeled by dunite. (B) Cratering starts by shock wave-induced, crustal-scale excavation of a bowl-shaped transient cavity. (C) Gravitational instability of the transient cavity causes uplift of the crater center and concomitant inward slumping of the cavity wall. (D) Collapse and radial outward displacement of uplifted material over inward-slumped cavity wall segments. Red bars indicate stretching directions toward the end of cratering. White arrows indicate crustal flow during crater modification and subsequent relaxation. (For interpretation of the references to color in this figure legend, the reader is referred to the web version of this article.)

\subsection{Timing of dike formation}

Assuming that the Vredefort melt sheet experienced differentiation, the duration of melt emplacement can be constrained based on the time required for the physicochemical process of differentiation to complete. Assuming that the thickness of the Vredefort impact melt sheet was similar to that of the solidified impact melt sheet of the Sudbury impact structure, estimated at 3-5 km (Grieve et al., 1991), and that heat loss was conductive, solidification of the melt sheet was on the order of $10^{6}$ years ((Ivanov and Deutsch, 1999); Ivanov, 2005). However, in case of convective cooling, which is more likely, given initial superheating of the melt sheet and the large temperature gradients imparted by colder target rock below and the atmosphere above the melt sheet, solidification of the sheet is estimated to have occurred within $10^{3}$ to $10^{4}$ years after impact (Zieg and Marsh, 2005), placing an upper limit on the timescale of melt emplacement in the dikes. Differentiation of the melt sheet into felsic and mafic layers likely occurred within $10^{3}$ years based on comparison with the chemical evolution of large-scale magma chambers (Hawkesworth et al., 2003), although this process may have taken place much faster. Therefore, the KGA, EDA, and core dikes must have been emplaced within $10^{3}$ years after impact, and the KGB and EDB portions must have formed between $10^{3}$ and $10^{4}$ years after the impact. This timescale estimation is consistent with previous considerations of impact melt dike formation at Sudbury (e.g., Dietz, 1961; Wichman and Schultz, 1993; Hecht et al., 2008), and the calculated duration of crystallization of the Bushveld Igneous Complex, which reached its solidus within $10^{5}$ years (Cawthorn and Walraven, 1998), and completed its subsolidus crystallization within $10^{6}$ years (Zeh et al., 2015). Hydrothermal activity can take place at significantly cooler temperatures, and may have continued for up to $10^{6}$ years after the impact event (e.g., Kring et al., 2020). The relaxation of the crust also apparently continued after the melt sheet had reached the solidus, as the Daskop and Holfontein Dikes are displaced by post-crystallization faults, which, in the absence of post-cratering orogenic deformation, must be attributed to deformation as a consequence of crustal relaxation (Fourie et al., 2019; Clark et al., 2021), demonstrating that the crustal relaxation of Vredefort continued for more than $10^{4}$ years after the impact, perhaps up to $10^{6}$ years.

\section{Conclusions}

Besides Sudbury, the Vredefort impact structure is the only known basin-sized terrestrial impact structure with exposed deep portions of underlying crust. Investigation of the Granophyre Dikes at Vredefort suggests that impact melt dikes were emplaced episodically by postcratering relaxation of crust below the crater floor. Impact-induced crustal relaxation occurs on timescales of tens of thousands to hundreds of thousands of years. Thus, impact melt dikes such as the Granophyre Dikes at Vredefort provide important information on the post-shock development of large complex craters on rocky planetary bodies.

Specific results of our work are:

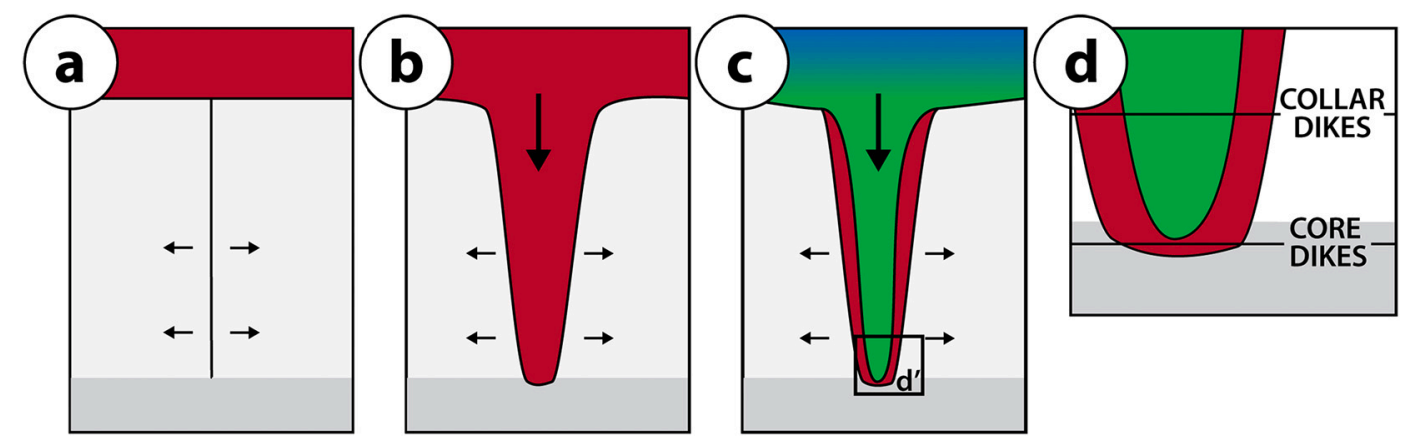

Fig. 10. Schematic diagram illustrating the process of Granophyre Dike formation (not to scale). A) The homogenized melt sheet rests on top of the post-impact crust. An initial fracture in the crust begins to develop, extending down to a kinematic boundary. B) Before melt sheet differentiation, the dilating fracture opens sufficiently for melt to be extracted from the lowermost portions of the melt sheet to fill the fracture. Extension is driven by crustal re-equilibration (Fig. 9). C) After melt sheet differentiation and solidification of the earlier melt phase within the dike, extension continues, allowing the fracture to dilate further, so that a second pulse of melt flows into the fracture. The melt is sampled from the lowermost mafic portions of the melt sheet. D) Referencing inset d', after crystallization of the second pulse of melt, the present-day configuration is achieved. Because the core-collar dikes are less deeply eroded than the core dikes, the later pulse of melt remains visible. 
1. Geophysical results show that Granophyre Dikes in the core of the Vredefort structure do not extend deeper than $5 \mathrm{~m}$ below the present erosional surface. Alternative interpretations of the geophysical data do not satisfactorily explain the observations and the numerical modeling results. The core-collar dikes extend $\geq 9 \mathrm{~m}$ below the present erosional surface.

2. The core dike termini are observed around the present erosion surface, which can be explained by the abrupt directional change in rock displacements at this surface, serving as a kinematic velocity discontinuity.

3. The core and core-collar Granophyre Dikes are geochemically indistinguishable. However, an intermediate composition phase is present in the central parts of the core-collar dikes that is distinct from but genetically related to the more felsic dike composition.

4. The erosional difference between the core dikes and core-collar dikes is small, but apparently demonstrates that the more mafic phase extended to near the lowermost extent of the dikes.

5. The Granophyre Dikes formed as a result of melt flowing downwards from the melt sheet through extensional fractures that dilated as a result of horizontal stretching of crust due to uplift of the crater floor.

6. The timescale of Granophyre Dike formation is constrained by the dike compositions, which relate to the chemical differentiation of the impact melt sheet. Felsic dike portions formed prior to intermediate dike portions. The timing of dike formation is constrained by the time necessary for a melt sheet to differentiate and solidify.

7. The process of crater formation generates an inherent crustal instability due to dynamic collapse of the transient crater and formation of a central uplift. This instability may then be accommodated in discreet periodic events over $10^{4}-10^{6}$ timescales through relaxation. The formation of Granophyre Dikes is a consequence of this process interacting with a differentiating melt sheet.

\section{Declaration of Competing Interest}

None.

\section{Acknowledgments}

The research is supported by the National Research Foundation of South Africa grant 106511 to E. Kovaleva, the GRAVITAS interdisciplinary research group supported by UFS, and project Ri 916/14-1 by the German Science Foundation awarded to U. Riller. The authors thank Christo Meyer, Muller Terblanche, late Dr. A.J. van Collar, and Cobus Janse van Rensburg for access to field locations. The authors thank Mrs. Megan Purchase for assistance with XRF analyses. We also thank Sean Gulick and Dr. Mario Rebolledo-Vieyra for their helpful and insightful reviews that greatly improved the manuscript.

\section{Appendix A. Supplementary data}

Supplementary data to this article can be found online at https://doi. org/10.1016/j.icarus.2021.114812.

\section{References}

Andrews-Hanna, J.C., Head, J.W., Johnson, B.C., Keane, J.T., Kiefer, W.S., McGovern, P. J., Neumann, G.A., Wieczorek, M.A., Zuber, M.T., 2018. Ring faults and ring dikes around the Orientale basin on the Moon. Icarus. 310, 1-20.

Bisschoff, A.A., 1988. The history and origin of the Vredefort Dome (South Africa). S. Afr. J. Sci. 84, 413-417.

Buchanan, C., Reimold, W.U., 2002. Planar deformation features and impact glass in inclusions from the Vredefort Granophyre, South Africa. Meteor. Planet. Sci. 37, 807-822.

Cawthorn, R.G., Walraven, F., 1998. Emplacement and crystallization time for the Bushveld Complex. J. Petrol. 39, 1669-1687.

Clark, M.D., Kovaleva, E., Huber, M.S., Fourie, F., Harris, C., 2021. Post-impact faulting of the Holfontein granophyre dike of the Vredefort impact structure, South Africa, inferred from remote sensing. Geophys. Geochem.: Geosci. 11, 96.
Collins, G.S., Melosh, H.J., Morgan, J.V., Warner, M.R., 2002. Hydrocode simulations of Chicxulub crater collapse and peak-ring formation. Icarus. 157, 24-33.

Collins, G.S., Patel, N., Davison, T.M., Rae, A.S.P., Morgan, J.V., Gulick, S.P., IODP-ICDP Expedition 364 Science Party, 2020. A steeply-inclined trajectory for the Chicxulub impact. Nat. Commun. 11, 1-10.

Dence, M.R., 1971. Impact melts. J. Geophys. Res. 76, 5552-5565.

Dietz, R.S., 1961. Vredefort ring structure: meteorite impact scar? J. Geol. 69, 499-516. Dressler, B., Reimold, W.U., 2004. Order or chaos? Earth-Sci. Rev. 67, 1-54.

Elkins-Tanton, L.T., Hager, B.H., 2005. Giant meteoroid impacts can cause volcanism. Earth Planet. Sci. Lett. 239, 219-232.

Fourie, F.D., Huber, M.S., Kovaleva, E., 2019. Geophysical characterization of the Daskop granophyre dike and surrounding host rocks, Vredefort impact structure, South Africa. Meteor. Planet. Sci. 54, 1579-1593.

French, B., Nielsen, R., 1990. Vredefort bronzite granophyre: chemical evidence for origin as a meteorite impact melt. Tectonophysics. 171, 119-138.

French, B.M., Orth, C.J., Quintana, L.R., 1989. Iridium in the Vredefort bronzite granophyre: Impact melting and limits on a possible extraterrestrial component. In: Proceedings of the 19th Lunar and Planetary Science Conference, pp. 733-744.

Friese, A.E.W., Charlesworth, E.G., McCarthy, T.S., 1995. Tectonic Processes within the Kaapvaal Craton during the Kibaran (Grenville) Orogeny: Structural, geophysical, and Isotopic Constraints from the Witwatersrand Basin and Environs, vol. \#292. University of Witwatersrand Information Circular, $62 \mathrm{p}$.

Gibson, R.L., Reimold, W.U., Stevens, G., 1998. Thermal-metamorphic signature of an impact event in the Vredefort Dome, South Africa. Geology. 26, 787-790.

Glover, P.W.J., 2015. Geophysical properties of the near surface earth: Electrical properties. In: Schubert, Gerald (Ed.), Treatise on Geophysics, , 2nd editionVol 11. Elsevier, Oxford, pp. 89-137.

Grieve, R.A., Reimold, W.U., Morgan, J., Riller, U., Pilkington, M., 2008. Observations and interpretations at Vredefort, Sudbury, and Chicxulub: towards an empirical model of terrestrial impact basin formation. Meteorit. Planet. Sci. 43, 855-882.

Grieve, R.A.F., Stofffler, D., Deutsch, A., 1991. The sudbury structure: controversial or misunderstood? J. Geophys. Res. 96, 22753-22764.

Grieve, R.A.F., Therriault, A., 2000. Vredefort, Sudbury, Chicxulub: three of a kind? Annu. Rev. Earth Planet. Sci. 28, 305-338.

Hart, R.J., Andreoli, M.A.G., Tredoux, M., De Wit, M.J., 1990. Geochemistry across an exposed section of Archaean crust at Vredefort, South Africa: with implications for mid-crustal discontinuities. Chem. Geol. 82, 21-50.

Hart, R.J., Moser, D., Andreoli, M.A.G., 1999. Archean age for the granulite facies metamorphism near the center of the Vredefort structure, South Africa. Geology 27, 1091-1094.

Hawkesworth, C., George, R., Turner, S., Zellmer, G., 2003. Estimating the time scales of magmatic processes. Develop. Volcanol. 5, 23-43.

Hecht, L., Wittek, A., Riller, U., Mohr, T., Schmitt, R.T., Grieve, R.A.F., 2008. Differentiation and emplacement of the Worthington offset dike of the Sudbury impact structure, Ontario. Meteorit. Planet. Sci. 43, 1659-1679.

Henkel, H., Reimold, W.U., 1998. Integrated geophysical modelling of a giant, complex impact structure: anatomy of the Vredefort structure, South Africa. Tectonophys. $287,1-20$

Huber, M.S., Kovaleva, E., Riller, U., 2020. Modeling the geochemical evolution of impact melts in terrestrial impact basins: Vredefort granophyre dikes and Sudbury offset dikes. Meteorit. Planet. Sci. 55, 2320-2337.

Huber, M.S., Kovaleva, E., Clark, M., Prevec, S., 2021. Inhomogeneous distribution of lithic clasts within the Daskop Granophyre Dike, Vredefort Impact Structure: Implications for emplacement of impact melt in large impact structures. In: Reimold, W.U., Koeberl, C. (Eds.), Large Meteorite Impacts and Planetary Evolution VI. Geological Society of America Special Paper, p. 550.

Ivanov, B., 2005. Numerical modeling of the largest terrestrial meteorite craters. Sol. Syst. Res. 39, 381-409.

Ivanov, B.A., Deutsch, A., 1999. Sudbury impact event: cratering mechanics and thermal history. In: Dressler, B.O., Sharpton, V.L. (Eds.), Large Meteorite Impacts and Planetary Evolution II, vol. 339. Geological Society of America, Boulder, Colorado, pp. 389-397.

Kamo, S.L., Reimold, W.U., Krogh, T.E., Colliston, W.P., 1996. A 2.023 Ga age for the Vredefort impact event and a first report of shock metamorphosed zircons in pseudotachylitic breccias and granophyre. Earth Planet. Sci. Lett. 144, 369-387.

Kenkmann, T., Poelchau, M.H., Wulf, G., 2014. Structural geology of impact craters. J. Struct. Geol. 62, 156-182.

Koeberl, C., Reimold, W.U., Shirey, S., 1996. Re-Os isotope and geochemical study of the Vredefort Granophrye: clues to the origin of the Vredefort structure, South Africa. Geology. 24, 913-916.

Kovaleva, E., Huber, M.S., Zaccarini, F., 2018. Petrography and geochemistry of coarsecrystalline veins within Vredefort Granophyre, Vredefort impact structure, South Africa. South Afr. J. Geol. 121, 383-402.

Kovaleva, E., Zamyatin, D.A., Habler, G., 2019. Granular zircon from Vredefort granophyre (South Africa) confirms the deep injection model for impact melt in large impact structures. Geology. 47, 691-694.

Kring, D., 1995. Composition of Earth's continental crust as inferred from the compositions of impact melt sheets. In: Proceedings from the 28th Lunar and Planetary Science Conference, 28, pp. 763-764.

Kring, D.A., Tikoo, S.M., Schmieder, M., Riller, U., Rebolledo-Vieyra, M., Simpson, S.L., Osinski, G.R., Gattacceca, J., Wittmann, A., Verhagen, C.M., Cockell, C.S., Coolen, M. J.L., Longstaffe, F.J., Gulick, S.P.S., Morgan, J.V., Bralower, T.J., Chenot, E., Christeson, G.L., Claeys, Ph., Ferrière, L., Gebhardt, C., Goto, K., Green, S.L., Jones, H., Lofi, J., Lowery, C.M., Ocampo-Torres, R., Perez-Cruz, L., Pickersgill, A.E., Poelchau, M.H., Rae, A.S.P., Rasmussen, C., Sato, H., Smit, J., Tomioka, N., Urrutia- 
Fucugauchi, J., Whalen, M.T., Xiao, L., Yamaguchi, K.E., 2020. Probing the hydrothermal system of the Chicxulub impact crater. Sci. Adv. 6, eaaz3053.

Lafrance, B., Bygnes, L., McDonald, A.M., 2014. Emplacement of metabreccia along the whistle offset dike, Sudbury: implications for post-impact modification of the Sudbury impact structure. Can. J. Earth Sci. 51, 466-484.

Lana, C., Reimold, W.U., Gibson, R.L., Koeberl, C., Siegesmund, S., 2004. Nature of the Archean midcrust in the core of the Vredefort dome, central Kaapvaal craton, South Africa. Geochim. Cosmochim. Acta 68, 623-642.

Le Bas, M.J., Le Maitre, R.W., Streckeisen, A., Zanettin, B., 1986. A chemical classification of volcanic rocks based on the total alkali-silica diagram. J. Petrol. 27, 745-750.

Le Maitre, R.W., Streckeisen, A., Zanettin, B., Le Bas, M.J., Bonin, P., Bateman, G., Bellieni, G., Dudek, A., Efremova, S., Keller, J., Lamere, J., Sabine, A., Schmid, R., Sorensen, H., Woolley, A.R., 2002. Igneous Rocks: A Classification and Glossery of Terms, Recommendations of the International Union of Geological Sciences, Subcommission of the Systematics of Igneous Rocks. Cambridge University Press.

Lieger, D., Riller, U., 2012. Emplacement history of granophyre dikes in the Vredefort impact structure, South Africa, inferred from geochemical evidence. Icarus. 219, 168-180.

Lightfoot, P., Keays, R.R., Morrison, G.G., Bite, A., Farrell, K.P., 1997. Geochemical relationships in the Sudbury igneous complex: origin of the Main Mass and Offset Dikes. Econ. Geol. 92, 289-307.

Loke, M.H., 2020. Tutorial: 2-D and 3-D Electrical Imaging Surveys (Electronic version available from). http://www.geotomosoft.com/downloads.php.Mathieu.

Mathieu, L., Riller, U., Gibson, L., Lightfoot, P., 2021. Structural controls on the localization of the mineralized Copper Cliff embayment and the Copper Cliff offset dyke, Sudbury Igneous Complex, Canada. Ore Geol. Rev. 133, 104071.

Morgan, J.V., Gulick, S.P.S., Bralower, T., Chenot, E., Christeson, G.L., Claeys, P., Cockell, C.S., Collins, G.S., Coolen, M., Ferrière, L., Gebhardt, C., Goto, K., Jones, H., Kring, D.A., Le Ber, E., Lofi, J., Long, X., Lowery, C., Mellet, C., Ocampo-Torres, R., Osinski, G.R., Perez-Cruz, L., Pickersgill, A., Poelchau, M., Rae, A., Rassmussen, C., Rebolledo-Vieyra, M., Riller, U., Sato, H., Schmitt, D., Smit, J., Tikoo-Schantz, S., Tomioka, N., Urrutia-Fucugauchi, J., Whalen, M.T., Wittmann, A., Yamaguchi, K., Zylbermann, W., 2016. The formation of peak rings in large impact craters. Science. 354, 878-882.

Moser, D.E., 1997. Dating the shock wave and thermal imprint of the giant Vredefort impact, South Africa. Geology. 25, 7-10.

Pilles, E.A., Osinski, G.R., Grieve, R.A.F., Coulter, A.B., Smith, D., Bailey, J., 2017. The Pele offset dikes, Sudbury impact structure, Canada. Can. J. Earth Sci. 55, 230-240.

Pretorius, S.J., 2009. The Role of Geohydrology in the Determination of a Spatial Development Framework in the Vredefort Dome World Heritage Site. PhD thesis. North West University, South Africa.
Prevec, Büttner, 2018. Multiphase emplacement of impact melt sheet into the footwall: offset dykes of the Sudbury igneous complex, Canada. Meteorit. Planet. Sci. 53, 1301-1322.

Rae, A.S.P., Collins, G.S., Morgan, J.V., Poelchau, M., Riller, U., Timms, N., Cavosie, A., Salge, T., Davison, T.M., Lofi, J., Ferrière, L., 2019. Observational constraints on numerical models of Peak-Ring formation, LPI contributions no. 2136. In: Large Meteorite Impacts and Planetary Evolution VI. Geological Society of America, p. 5059.

Riller, U., 2005. Structural characteristics of the Sudbury impact structure, Canada: impact-induced versus orogenic deformation-a review. Meteorit. Planet. Sci. 40, 1723-1740.

Riller, U., Poelchau, M.H., Rae, A.S., Schulte, F.M., Collins, G.S., Melosh, H.J., Grieve, R. A., Morgan, J.V., Gulick, S.P., Lofi, J., Diaw, A., 2018. Rock fluidization during peakring formation of large impact structures. Nature. 562, 511-518.

Schreyer, W., 1983. Metamorphism and fluid inclusions in the basement of the Vredefort dome, South Africa: guidelines to the origin of the structure. J. Petrol. 24, 26-47.

Telford, W.M., Geldart, L.P., Sheriff, R.E., 1990. Applied Geophysics, 2nd edition. Cambridge University Press, Cambridge, USA.

Therriault, A., Reimold, W.U., Reid, A.M., 1996. Field relations and petrography of the Vredefort Granophyre. S. Afr. J. Geol. 99, 1-21.

Therriault, A.M., Reimold, W.U., Reid, A.M., 1997. Geochemistry and impact origin of the Vredefort Granophyre. S. Afr. J. Geol. 100, 115-122.

Van der Walt, I.J., Pretorius, S.J., Schoeman, C.B., 2010. The role of geohydrology in the determination of a spatial development framework in the Vredefort Dome World Heritage Site. Water. 2, 742-772.

Wichman, R.W., Schultz, P.H., 1993. Floor-fractured crater models of the Sudbury structure, Canada: implications for initial crater size and crater modification. Meteoritics. 28, 222-231.

Willemse, J., 1937. On the old granite of the Vredefort region and some of its associated rocks. Trans. Geol. Soc. South Afr. 40, 43-119.

Winchester, J.A., Floyd, P.A., 1977. Geochemicaldiscrimination of different magma series and their differentiation products using immobile elements. Chem. Geol. 20, 325-343.

Wittmann, A., Kenkmann, T., Schmitt, R.T., Hecht, L., Stöffler, D., 2004. Impact-related dike breccia lithologies in the ICDP drill core Yaxcopoil-1, Chicxulub impact structure, Mexico. Meteorit. Planet. Sci. 39, 931-954.

Youssof, M., Thybo, H., Artemieva, I., Levander, A., 2013. Moho depth and crustal composition in Southern Africa. Tectonophysics. 609, 267-287.

Zeh, A., Ovtcharova, M., Wilson, A.H., Schaltegger, U., 2015. The bushveld complex was emplaced and cooled in less than one million years - results of zirconology, and geotectonic implications. Earth Planet. Sci. Lett. 418, 103-114.

Zieg, M., Marsh, B., 2005. The Sudbury Igneous complex: viscous emulsion differentiation of a superheated impact melt sheet. Geol. Soc. Am. Bull. 117, 1427-1450. 